\title{
Avant-garde Artists vs. Reindeer Herders: The Kazym Rebellion in Aleksei Fedorchenko's Angels of the Revolution (2014)
}

Andrei Rogatchevski (UiT The Arctic University of Norway)

7 he Russian Bolshevik Revolution took place in October 1917, in the capital city of Petrograd, yet in some of Russia's remote corners the effects of that revolution could not be felt in earnest until much later. One of the topics that has fascinated scholars and authors alike is the revolution's influence on the indigenous peoples of the North. Ever since Mikhail Speranskii's administrative statutes of 1822, the tsarist government largely left such peoples, especially those resident in Siberia, to their own devices. As for the Soviet government, acting via the Committee for the Assistance to the Peoples of the Outlying Districts of the North (also known as the Committee of the North, 1924-1935), it initially tried to keep an uneasy balance between attempting to involve peoples of the North in building socialism, on the one hand, and preserving their unique traditional lifestyles, on the other. Needless to say, the latter approach, inevitably and to a significant degree, detached the indigenous peoples of the North from the process of socialist construction, at least for a while.

However, once Stalin had assumed full and unassailable leadership of Soviet Russia, "nobody was to be exempt from either progress or ... equality. ... The native tribes of the northern borderlands were obliged to join the modern ... world without delay." 1 Yet "of all the non-Russian subjects of the Russian state, ... it is the circumpolar hunters and gatherers who have proved the most difficult to reform... . The natives refused to play their parts and failed to demonstrate that they had [been] proper ... proletarians." 2

\footnotetext{
1 Yuri Slezkine, Arctic Mirrors: Russia and the Small Peoples of the North (Ithaca: Cornell University Press, 1994), 389.

2 Ibid., ix and 390.
} 
On a number of occasions, the natives' resistance to socialist reforms was tenacious, long-lasting, and violent. One prime example is the Kazym rebellion of 1931-1934, aimed against the Kazym kultbaza (or cultural station), which officially opened in the autumn of 1931 in the Amninskie iurty settlement, some 750 miles to the northeast of Ekaterinburg (then Sverdlovsk), in what is now known as the Khanty-Mansi autonomous district. ${ }^{3}$

The Omsk ethnographer and anthropologist Innokentii Shukhov, who travelled to the Kazym river valley in 1914-1915 to study the local population, characterized the Kazym Khanty (in contrast with other Khanty inhabiting the adjacent territories further to the north and to the south) as "hard-working, tough, not too demanding and relatively sober people... . Kazym Khanty have not been affected by Russian culture overly much. This may be one of the main reasons why they are relatively prosperous and not dying out." 4

Some fifteen years later, these same Kazym Khanty (chiefly engaged in reindeer husbandry), together with the neighboring Nentsy (predominantly fishermen), staged a months-long rebellion, which was eventually suppressed with the help of special forces and airplanes, no less. The center of the rebels' attention, the Kazym kultbaza, was one of many cultural stations - built on the instructions of the Committee of the North as strongholds of Soviet civilization-in strategically located, hard to reach places. A kultbaza was

a communist mission that would house a hospital, a veterinary center, a school, a museum, scientific laboratories, and a House of the Native, where local folks could relax with a cup of tea and a newspaper. This way, a cold and hungry teacher or doctor would not have to chase the nomads ...; on the contrary, attracted by the useful services the station had to offer, the natives would come by themselves. ${ }^{5}$

3 For more on the Kazym rebellion, see Olga Ernykhova, Kazymskii miatezh: Ob istorii Kazymskogo vosstaniia 1933-34 gg. (Novosibirsk: Sibirskii khronograf, 2003). The following account of real-life events is taken from this well-documented source.

4 I. N. Schuchov, Der Fluss Kazym und seine Anwohner: Ergebnisse einer 1914 unternommenen Exkursion, trans. by Katharina Oestreich-Geib (München: Veröffentlichungen des Finnisch-Ugrischen Seminars an der Universität München, 1980), 26. All translations into English are mine, unless indicated otherwise.

5 Slezkine, Arctic Mirrors, 157. In addition to stationary kultbazy, there also existed so-called red tents, "a sort of travelling kultbazy modelled after the mobile churches of the missionaries” (ibid., 229). 
The Kazym kultbaza consisted of fourteen buildings, which together provided services that the locals needed most (educational, medical, veterinary, economic, and so on). There was a boarding school for fifty pupils; two hospitals (one for humans, another for animals; the vets reportedly focused more on studying reindeer than on treating them); a guest house; a vegetable storage building; a power station; and living quarters for thirty-seven members of staff, including a librarian and a local historian.

Kultbazy were meant to function not only as beacons of Soviet culture and enlightenment but also as "institutions controlling the process of collectivization." ${ }^{\prime}$ It is in this capacity that the Kazym kultbaza caused a "protest among the locals, for whom it came to symbolize the new policy of compulsory collective ownership [obobshchestvlenie], implemented on a mass scale." Two primary reasons for the rebellion are cited by Ernykhova:

1. changes in taxation practices (taxes for the allegedly affluent reindeer owners became extortionately high, and could only be imposed by threat of firearms); 8

2. the involuntary recruitment of boarding school pupils (to secure the parents' consent to the schooling, their rifles could be temporarily confiscated). ${ }^{9}$

Furthermore, the state could not supply Kazym with enough foodstuffs. In 1932-1933, there arrived $240 \mathrm{t}$ less flour, 8,500 kg less sugar, and 7,049 kg less butter than required. Despite the high demand, shops did not have washbasins, soap, hardware, utensils, cauldrons, kettles, cups, and so on.

The first phase of resistance, led by the former chairman of the Kazym indigenous district council (raituzsovet) Ivan Ernykhov, began in the autumn of 1931. The demands included the abolition of kulak-related taxation, the return of the boarders home, and the removal of kultbaza from Kazym. Some dissenting Khanty were arrested. A number of Khanty fami-

6 See Ernykhova, Kazymskii miatezh, 17.

7 Ibid., 22.

8 According to the statistical data, in August 1932 in Kazym, those categorized as "workers for hire (batraki) had 2.5 reindeer per household; the poor (bedniaki), 12 reindeer; the mid-income ones (seredniaki), 41 reindeer; and the rich (kulaki), 244 reindeer" (ibid., 40). At the same time, "to provide sustenance for a family of five and to ensure the herd's natural growth, it was necessary to own at least 43 reindeer" (ibid., 43).

9 "Removing children from their families against their will was perceived as hostage-taking to ensure the implementation of Soviet policies" (ibid., 48). 
lies chose to disappear into the tundra. In the process, some parents picked up their children from school two days before its December closure in such haste that they got someone else's offspring and had to exchange them for their own on the way. ${ }^{10}$

The rebellion's second phase began in the summer of 1933, when the authorities decided to start commercial fishing on Lake Num-to, believed by the locals to be a sacred place of residence for the goddess of Kazym, Kasum imi. This annoyed many Nentsy, who joined the Khanty protests. ${ }^{11}$ In order to try to resolve the conflict, a team of negotiators was dispatched to the Nentsy camp in December 1933. Among the negotiators were their leader Polina Shneider (a plenipotentiary from the Urals' Regional Communist Party Committee), Petr Astrakhantsev (the chairman of the Berezovo district executive committee, under whose administrative jurisdiction Kazym then belonged), Petr Smirnov (deputy head of the Kazym kultbaza), Nikolai Nesterov (director of the local branch of consumers' cooperative, or integral'noe tovarishchestvo) and Zakhar Posokhov (of the Berezovo OGPU, that is, Soviet secret police). These five were taken hostage by the Nentsy (in the hope that this would help for the rebels' demands to be met and the arrested Khanty to be released), and later strangled to death with ropes. ${ }^{12}$

The rebellion was finally quashed in February 1934. Almost 1,000 reindeer were confiscated by the state. Eighty-eight people were arrested. Some of them died during the investigation. Fifty-two were charged, three acquitted, eleven shot, and the rest were imprisoned. ${ }^{13}$ As recently as 1993, the Tiumen prosecutor's office refused to exonerate the forty-nine people concerned.

The Kazym rebellion was, to all intents and purposes, a "reaction against the policy of unceremonious interference in the life of the indigenous population, the destruction of centuries-long customs and the imposition of unacceptable forms of economic management." ${ }^{14}$ Curiously, the economic aspect, presumably the weightiest on the list of reasons for the

10 Ibid., 57. After that, the boarders at school (mostly those whose parents lived on the kultbaza, anyway) remained in the single digits.

11 The catch was too large, could not be transported anywhere and was left to rot away (see ibid., 67).

12 According to some reports, the dead were scalped and Shneider had her breasts cut off (see ibid., 77).

13 See ibid., 82-83.

14 Ibid., 91. 
revolt, ${ }^{15}$ is entirely missing from the heavily fictionalized film version of the Kazym events, Angely revoliutsii (Angels of the Revolution), directed by Aleksei Fedorchenko in 2015. ${ }^{16}$

The film's action begins on 6 April 1934. This date is written on a blackboard in a classroom in a wooden hut at the kultbaza, indicating the day when the Khanty suddenly take their children away from the boarding school. At the same time, it functions as a disclaimer warning the viewer about the film's fictional nature (by 6 April 1934, the Kazym rebellion was, of course, well and truly over). However, Angely revoliutsii does not wish to shed its factual origin completely. Shortly before the opening credits, an inscription appears: "The film is based on a true story."

In Fedorchenko's narrative, the economic disagreements in the conflict between the Nentsy-cum-Khanty (appearing here as one indigenous entity, by and large) and the Soviet authorities are chiefly replaced with aesthetic ones. Polina Shneider (played by Daria Ekamasova) is sent to Kazym not by the Urals' Regional Party Committee but by the People's Commissariat for Nationalities (defunct since 1924), to draw the indigenous peoples to the Soviet cause by the force of art, because they "need culture." The particular kind of art, believed to be suitable for the task, is exemplified by a dream team of avant-gardists, Polina's Communist sympathiser friends since the times of the Russian Revolution and Civil War, whom she summons from their diverse places of abode and occupation to follow her into the northern wilds.

Petr (played by Pavel Basov) is a film director who is shooting a picture about the Mexican revolution (Sergei Eisenstein and his unfinished project Que viva México! served as the principal background for this character). ${ }^{17}$ Played by Aleksei Solonchev, Smirnov (also called Petr and therefore referred to in the film by his surname to avoid confusion) is a teacher and theatre director, who allegedly worked once at the Moscow Latvian Theatre Skatuve ("Stage"),

15 Cf. the Kazym dwellers' statement: "It is impossible to live under the Soviets: we all go hungry, they don't give us any bread yet make us work" (ibid., 87).

16 The film has received much praise and, among others, in 2014, a Marcus Aurelius Award at the Rome Film Festival; a Cineuropa Award at the Lisbon \& Estoril Film Festival; a Special Award at the Tallinn Black Nights Film Festival; and, in 2015, a prize of the Guild of Film Critics and Film Scholars for Best Direction at the Open Russian Film Festival Kinotavr; and the Best Director prize at the Yakutsk International Film Festival. It was also named the best film in the Russian program at the 2015 Moscow International Film Festival.

17 See Valerii Kichin, "Shamany protiv revoliutsii: Aleksei Fedorchenko rasskazal v Rime o stolknovenii tsivilizatsii,” Rossiiskaia gazeta, October 22, 2014, accessed April 28, 2018, https://rg.ru/2014/10/22/film-site.html. 
liquidated in 1938, and not in 1929, as Angely revoliutsii claims. ${ }^{18}$ Zakhar (played by Georgii Iobadze) is a sculptor and photographer. His character is partly based on the Mordvin sculptor Stepan Erzia (1876-1959), famous for works such as his 1920 monument to the Liberated Laborer in Ekaterinburgand partly on the unknown author of the legendary 1918 monument to Judas Iscariot in Sviiazhsk. ${ }^{19}$ Nikolai (played by Konstantin Balakirev) is an architect and cremation enthusiast (this character is partly inspired by the artist and architect Nikifor Tamonkin, $1881-1951,{ }^{20}$ and probably also by the constructivist Dmitrii Osipov, 1887-1934, the designer of the New Donskoe Cemetery crematorium in Moscow, where many victims of Stalin's purges were burnt). ${ }^{21}$

Delivering, so-to-speak, a gift of modernity to reindeer herders, the avant-gardists present it, inter alia, in the form of a lecture on Suprematist painting, which utterly fails to impress. ${ }^{22}$ As a general tendency in the film, Angely's images repeatedly contrast ultra-modern urban civilization with its archaic rural counterpart (Figs. 1 and 2), not wishing to establish a superiority

18 See Ekaterina Vizgalova, "Aleksei Fedorchenko: 'Narod, kotoryi dolzhen byt' zainteresovan v svoei istorii, nichego ne znaet," Kino-teatr.ru, November 7, 2015, accessed April 28, 2018, http://www.kino-teatr.ru/kino/person/483/. Smirnov is probably inspired by Oswald Glazunov (Glaznieks), 1891-1947, who directed not only at Skatuve but also at the Vakhtangov theatre.

19 Ibid.

20 Ibid.

21 By his own admission, Fedorchenko had studied some 400 lives of Russian avant-gardists to discover weird and wonderful biographical facts that were subsequently ascribed to Angely's characters (see Olga Lunkova, "Shamany protiv Sovetskoi vlasti: V prokat vyshel film Alekseia Fedorchenko Angely revoliutsii," Teatral-online.ru, November 12, 2015, accessed April 28, 2018, http://www.teatral-online.ru/news/14674). Fedorchenko's Shneider, too, is an amalgam of the Russian revolutionaries Larisa Reisner (1895-1926), Aleksandra Kollontai (18721952), and Liudmila Mokievskaia-Zubok (1896-1919), as well as the food technologist Irina Sakharova (1880-c.1970) and, naturally, the real-life Polina Shneider (c. 1888-1933), who worked as a Bolshevik educationalist in Crimea before her transfer to the Urals in 1929. See Kichin, "Shamany protiv revoliutsii"; and Vizgalova, "Aleksei Fedorchenko."

22 Such a lecture, outlandish as it may seem, is an exaggeration but not a complete invention. At least one activist on an enlightening mission managed to attract the natives to his red tent "by playing his balalaika and showing pictures ... but the overall picture was not in favor of cultural revolution" (Slezkine, Arctic Mirrors, 230). Similar techniques (visuals and music) were used, for example, by Christian missionaries, in times and places that were quite remote from Russia and its revolutions. Thus, in the late eighteenth century, father Jean Pierron converted Mohawk Indians to Christianity by showing them images of the torments of hell. His successor, father Boniface, formed a choir of Indian children to lure into his chapel Indians who liked music (see chapters 34 and 35 of Leonard Cohen's Beautiful Losers [Toronto: McClelland and Stewart, 1966]). 


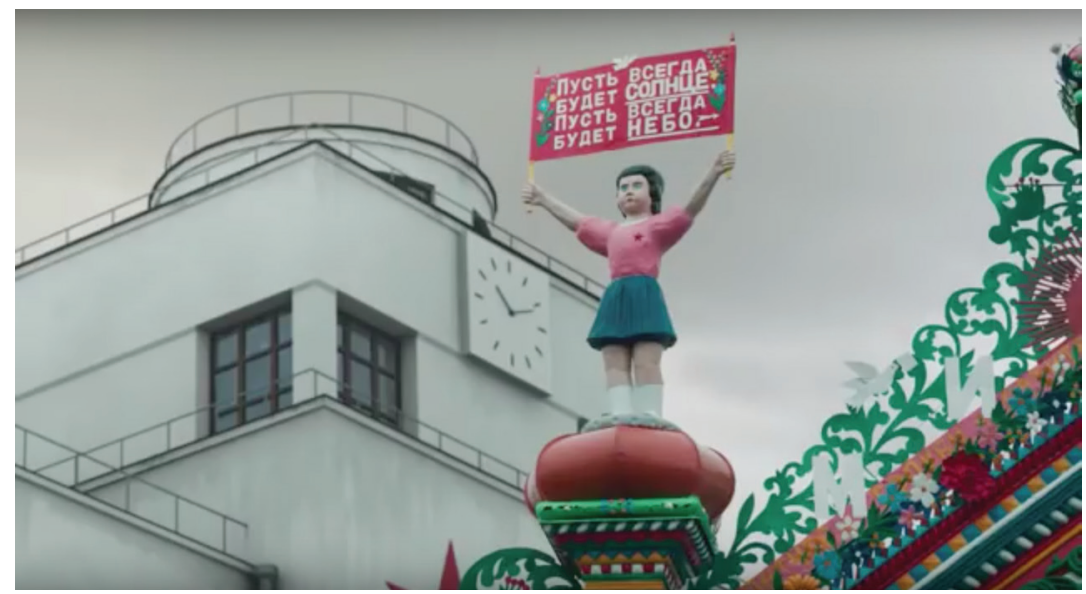

FIGURE 1: Courtesy of the 29 February film company.

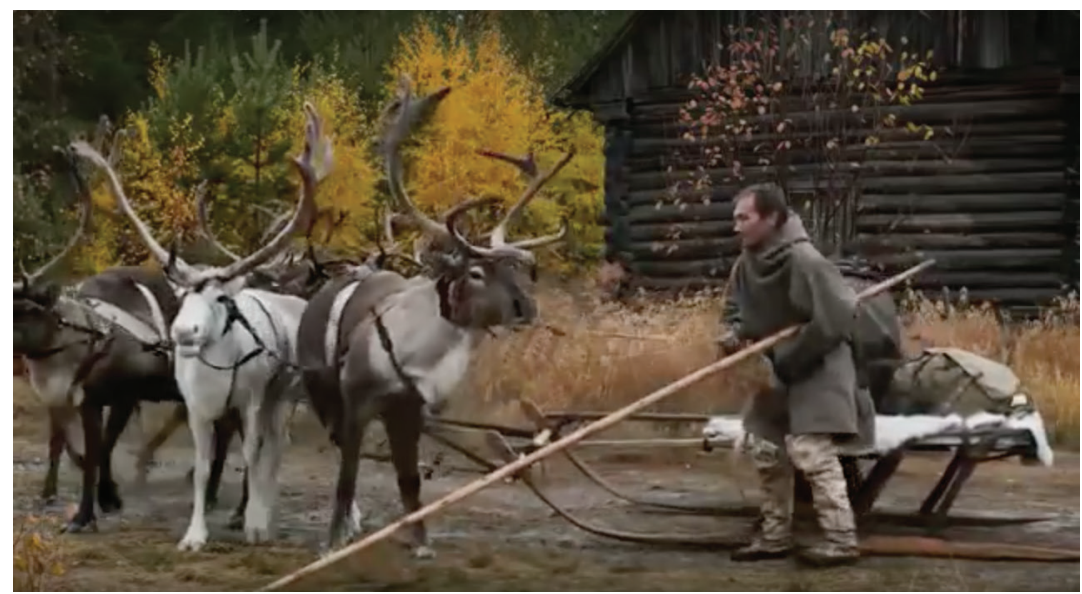

FIGURE 2: Courtesy of the 29 February film company.

of one over another. It is not that the two civilizations have nothing in common. Theatre, for example, is an essential part of both. Yet the indigenous theatre is represented by the handmade dolls of a Red Army soldier and a parka-clad shaman fighting each other (Fig. 3), ${ }^{23}$ while the concept of modern theatre is illustrated by, among other things, the amateur theatricals of Shneider's youth (Fig. 4) and the rehearsals of an avant-garde play at the boarding school,

23 Genuine Mansi folk theatre puppets were used for this episode, see Lunkova, "Shamany protiv Sovetskoi vlasti." 


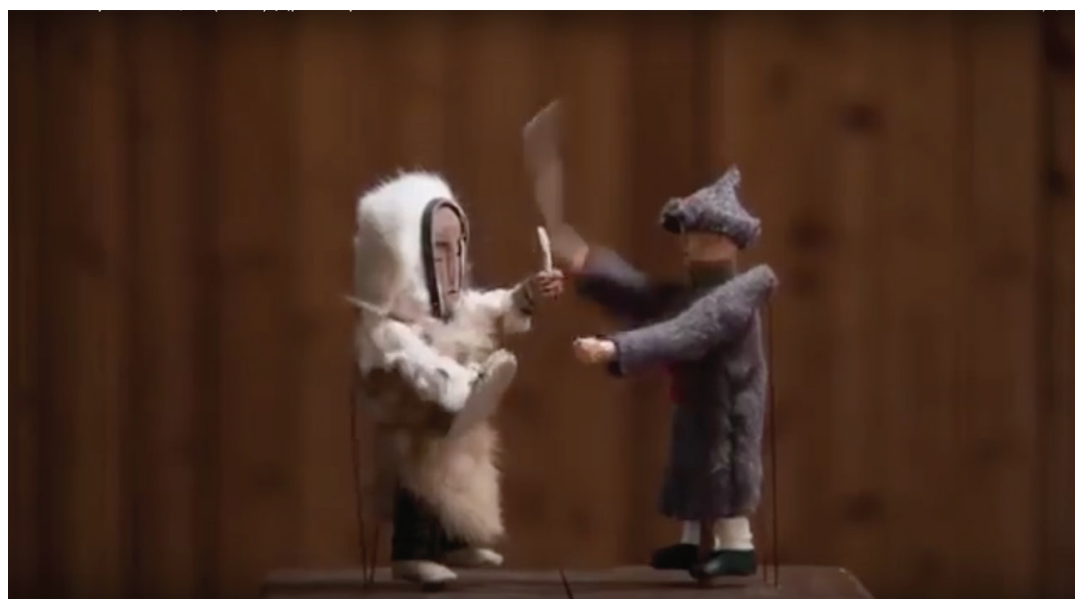

FIGURE 3: Courtesy of the 29 February film company.

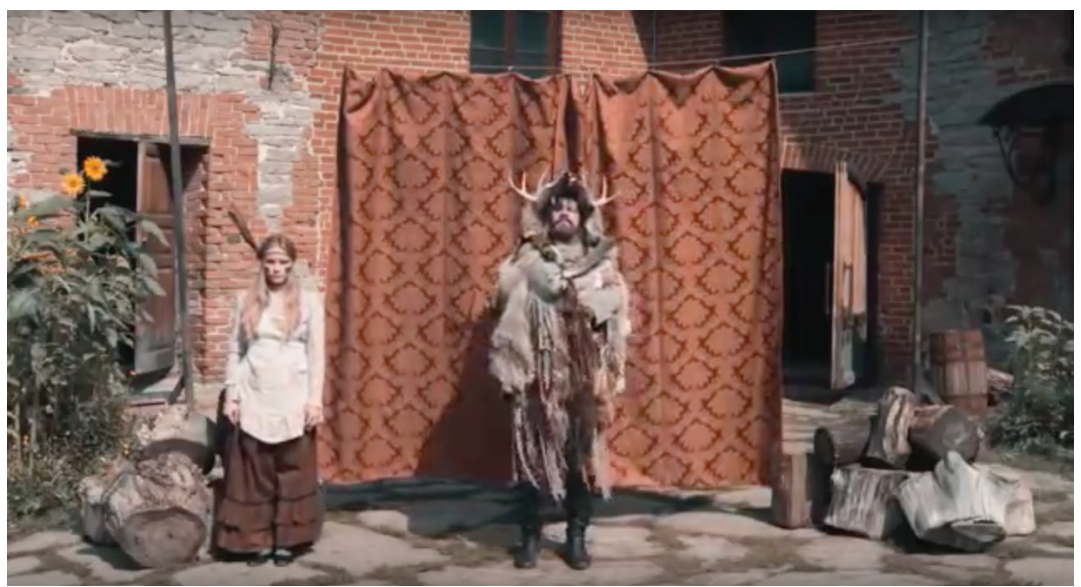

FIGURE 4: Courtesy of the 29 February film company.

immediately prior to the children's removal from it. However, in the end, few representatives of the two civilizations display much of a desire or capability of learning from each other, or even enough tolerance towards the differences that separate them. ${ }^{24}$

24 Cf., however, a wooden pagan miniature idol, a Russian Orthodox icon, and a statuette of Lenin, happily sharing a shelf for gods in an indigenous Kazym dwelling. 
In an especially revealing juxtaposition of scenes towards the end of the film, each culture displays its peak achievement. The avant-gardists set up a film projector to project surreal scenes through a window onto the smoke of the bonfire billowing into the night sky. In the very next scene, masked Khanty ritually slaughter a reindeer, chant over its dying body, and the shaman reveals that this has pleased the Khanty goddess. Both scenes are ineffably magical to each culture, and explain perhaps why the adherents are so passionate about their respective beliefs. ${ }^{25}$

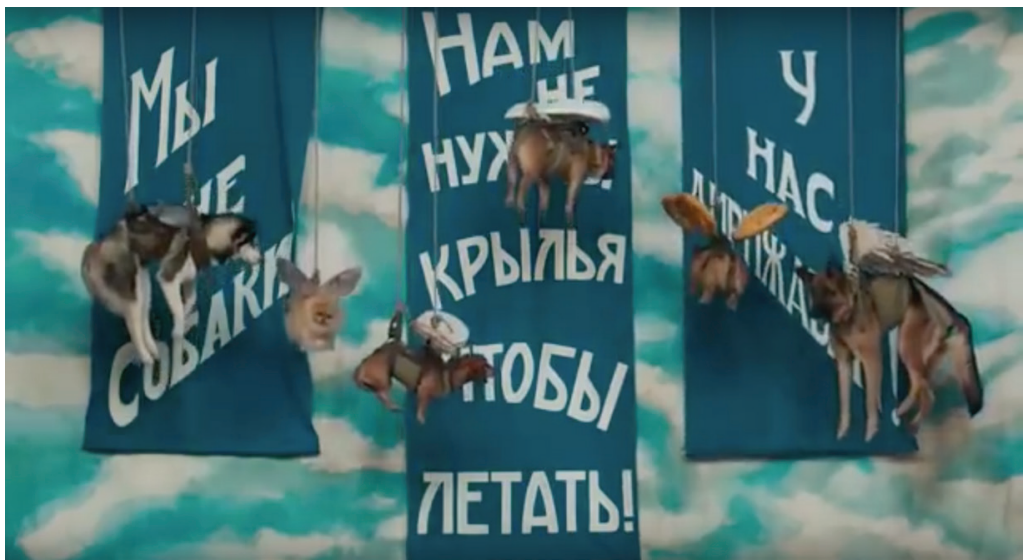

FIGURE 5: Courtesy of the 29 February film company.

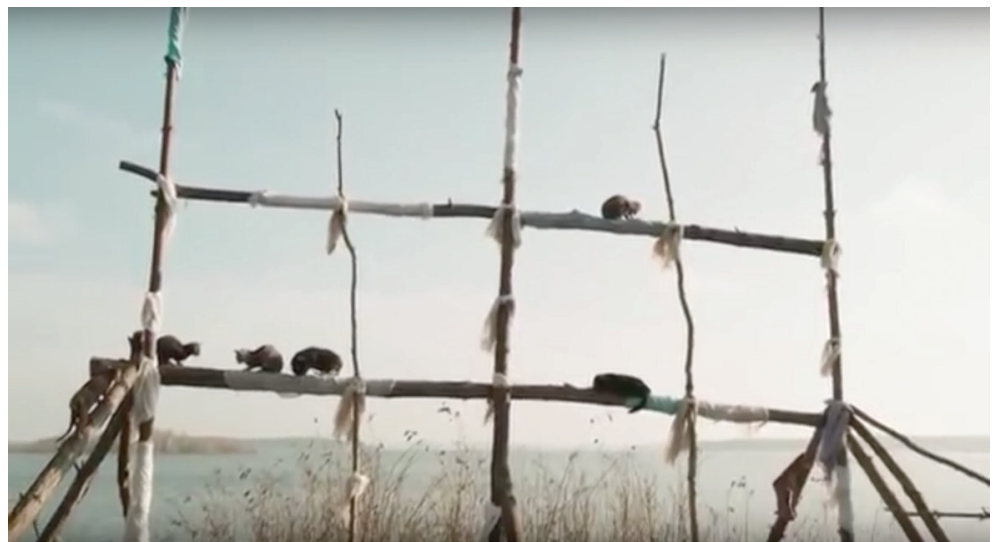

FIGURE 6: Courtesy of the 29 February film company.

25 Frederick C. Corney, "Aleksei Fedorchenko: Angels of the Revolution (Angely revoliutsii, 2014)," Kinokultura 48 (2015), accessed April 28, 2018, http://www.kinokultura. com/2015/48r-angely-revoliutsii.shtml. 
The mutual exclusivity of the two civilizations is demonstrated in particular through the juxtaposed multiple images of the (airborne) dogs (Fig. 5) taking part in a Bolshevik advertising campaign which promotes Soviet dirigibles, and of the cats (Fig. 6) occupying the sanctuary of the Kazym goddess (cat being her avatar and Kazym known as the Land of the Feline Elbow or, in the Kazym Khanty dialect, kan kunsh olan). As a desperate measure in showing the locals who's boss, Shneider, with her team in tow, intrudes into the sanctuary, removes the goddess's hat from her effigy and puts it on herself, like a crown of sorts, while turning some of the goddess's offerings into ad hoc stage props. Sadly, Shneider and her associates will later pay for this blasphemy with their lives.

Thus the indigenous population, appalled by the avant-gardists' radicalism, ultimately decides to reject the gift of modernity. In archaic societies, in the words of Marcel Mauss, a refusal "to accept [a gift is] the equivalent of a declaration of war." ${ }^{26}$ In Angely revoliutsii, the murderous acts of the Kazym rebellion symbolically take place on the eve of the seventeenth anniversary of the 1917 October Revolution. Yet another friend of Shneider's, an avant-garde composer called Ivan (Oleg Iagodin), ${ }^{27}$ who initially refused to come with her and others to Kazym (because he'd rather "hold a conductor's baton than a gun"), joins the military detachment mobilized in order to avenge his dead comrades. Having ordered Kazym Prince's (the rebels' leader) eyelids cut off, Ivan commits suicide under the air balloon which was meant to ascend into the sky to convince the natives that gods and spirits do not exist-but has never flown. It appears that in a mortal confrontation between the two civilizations, there are no winners. ${ }^{28}$

26 Marcel Mauss, The Gift: Forms and Functions of Exchange in Archaic Societies, transl. by Ian Cunnison (London: Cohen and West, 1966), 11.

27 His character has apparently been modelled after Lev Termen, 1896-1993 (see Kichin, "Shamany protiv revoliutsii"), and Arsenii Avraamov, 1886-1944 (see Aleksei Filippov, "Angely revoliutsii: Rossiia, kotoruiu my ne nashli," Kino-teatr.ru, November 1, 2015, accessed April 28, 2018, http://www.kino-teatr.ru/kino/art/pr/4181/).

28 Angely revoliutsii seems to belong to a range of Russian feature films dealing with various types of relationships between a titular nation and an ethnic (or ethno-religious) minority. In Fedorchenko's case, this relationship is portrayed as a tug-of-war. Also, the relationship can be represented as an idealized harmony (see, for example, Ivan Pyrev's 1941 Svinarka i pastukh-They Met in Moscow-about a love affair between a Russian swineherd and a Daghestani shepherd); a struggle between a David and a Goliath (see Aleksei Balabanov's 2010 Kochegar-The Stoker-about a Yakut dispatching several armed Russian gangsters with a ski pole); a case of divided loyalties, linked 
Whose side is Fedorchenko on? According to one of his interviews, he

tried not to take anybody's side. I wanted to portray altruists, not villains. The Khanty aren't bad and the Soviets had their uses, too, bringing in education and health care, which is good, isn't it ? $^{29}$ The film is about how difficult it is, when in Rome, not to do as the Romans would do (slozhno svoim ustavom oshchastlivit' chuzhoi monastyr'). ${ }^{30}$

There is no reason to doubt the sincerity of Fedorchenko's intentions, but did they fully materialize? It is obvious that his attempts to depict the Russian Revolution in the best possible light, choosing to focus on its arguably least controversial, "angelic" features, such as selfless idealism, innovation, and a burning desire to improve the quality of life for the dispossessed, have been largely successful. Simultaneously, Fedorchenko is not blind to the revolution's shortcomings, such as tactless invasiveness and needless brutality. What about the natives, though? Their representation in Angely revoliutsii is clearly not free from colonialist clichés, which tend to uphold "the binary opposition of civility versus savagery." ${ }^{31}$ In the film, the natives, especially in group scenes, are often shown as types, not individuals, wearing traditional dress and staring more or less straight into the camera, as if in those early anthropological photographs made by scientists in a "rational and objectivist [mode], characterized as it was by an instrumentalism that provided no opportunities for communication." 32

to protagonists' mixed origin (see Pavel Lungin's 1992 Luna Park, about a half-Jewish leader of a violent group of antisemitic skinheads); and a case of falling for the enemy (see Aleksandr Rogozhkin's 2002 Kukushka / The Cuckoo, about a reluctant threesome involving a Finnish private, a Soviet officer and a female Sami civilian at the end of the Continuation War in 1944).

29 Suprematism and cinema are not the only things brought as gifts to Kazym. A Singer sewing machine is presented to the mother of the first baby delivered at the kultbaza's hospital.

30 Alena Solntseva, "Aleksei Fedorchenko: 'Bogi skazali, chto nado prinesti chuzhikh v zhertvu,” The New Times, June 9, 2015, accessed April 29, 2018, https://newtimes.ru/articles/detail/98929/.

31 Anne Maxwell, Colonial Photography and Exhibitions: Representations of the "Native" People and the Making of European Identities (London and New York: Leicester University Press, 1999), 14.

32 Ibid., 10. Fedorchenko studied such photographs in archives, and creatively used some of their images in his film, see Kamila Mamadnazarbekova, "Aleksei Fedorchenko: 'Istoriia nas dognala," Vedomosti, June 23, 2015, accessed 30 April, 2018, https://www.vedomosti.ru/ lifestyle/characters/2015/06/24/597689-aleksei-fedorchenko-istoriya-nas-dognala. 
In order to portray "the most essentially 'unspoilt' native-least urbanized, most primitive, most different," 33 and thus emphasize the gap between the "advanced" culture of avant-gardists and the "backward" culture of reindeer herders, included in Angely are scenes such as "hunting with a primitive weapon" and "coming across a modern household item never seen by the indigene before." ${ }^{34}$ When Shneider pretends to be the Kazym goddess, she engages in a mock hunting with a spear (although Khanty and Nentsy have been using rifles of various kinds since the eighteenth century). In another film fragment, Kazym women are taught how to apply makeup in front of a mirror (even though mirrors of various kinds have been known in Siberia since time immemorial, and widely used in shamanic rituals, while the custom of some indigenous women in Siberia to paint their faces was recorded in the mid-nineteenth century, ${ }^{35}$ but of course had existed long before that).

Needless to say, "when represented as a 'child of nature', the colonial 'other' occupies a particular locus on the pseudo-biological social Darwinist continuum of human evolutionary development,"36 usually well below the person responsible for such visual representations. How does all this agree with Fedorchenko's statement that "ethnographic films should not be made

33 Jeremy Silvester, Patricia Hayes, and Wolfram Hartmann, “This Ideal Conquest': Photography and Colonialism in Namibian History," in The Colonising Camera: Photographs in the Making of Namibian History, ed. Wolfram Hartmann, Jeremy Silvester and Patricia Hayes (Cape Town: University of Cape Town Press, 1998), 17.

34 Cf. the canonical scenes of an Inuit hunting with a harpoon and listening to a gramophone in Robert J. Flaherty's pioneering Nanook of the North (1922), as well as two unidentified tribesmen hunting for a squirrel with a bow and arrows, and a Nentsy group encountering a gramophone in Dziga Vertov's Shestaia chast' mira (A Sixth Part of the World, 1926). The latter film also contains frequent shots of indigenous peoples staring at the camera en masse. Vertov was one of the prototypes for the character of Petr, see Vizgalova, "Aleksei Fedorchenko."

35 See Lydia Maria Child, Brief History of the Condition of Women in Various Ages and Nations, vol. 1 (New York: C. S. Francis, 1849), 183. Indigenous women indeed became the principal target of Soviet modernization, not necessarily as potential makeup wearers, of course, but as people who could introduce and maintain, for example, decent standards of hygiene. They were treated as "the mainspring through which the old way of life could be changed, the key to a healthier domestic and social life for the natives. Teach them new skills, and the children and men will have no choice but to follow" (Slezkine, Arctic Mirrors, 231). Nevertheless, "the emancipation campaign did not result in the creation of [a] much needed class of native allies" (ibid., 236).

36 Brent Harris, "Photography in Colonial Discourse: The Making of the 'Other' in Southern Africa, c. 1850-1950," in Hartmann, Silvester, and Hayes, The Colonising Camera, 21. 
from a position of superiority. It should be done the other way 'round, looking upwards, showing respect”? ${ }^{37}$

At first glance, Angely revoliutsii does not deviate too far from the Soviet tradition of ethnographic filmmaking, in which "indigenous peoples were simultaneously presented as primitive societies awaiting modernization and as complex cultures in need of research and preservation." ${ }^{38}$ However, upon closer examination, it transpires that Angely revoliutsii has acquired its shape not because Fedorchenko is incapable of breaking free from the Soviet film tradition. Neither is the film what it is because Fedorchenko and his principal co-scriptwriter on the project, Denis Osokin (a folklorist), approach their ethnographic material as outsiders. Oleg Fesenko's 2009 film Krasnyi led: Saga o khantakh Iugry (The Red Ice: A Iugra Khanty Saga), also devoted to the Kazym rebellion, still features Khanty as a "civilization of the 'noble savages,"39 even though it is based on a novel by the Khanty author Eremei Aipin, Bozh' ia mater' $v$ krovavykh snegakh (The Mother of God in the Blood-Spattered Snow [2002]). ${ }^{40}$ It rather appears as if in Angely revoliutsii Fedorchenko has consciously chosen to imitate, in an overblown manner and from an ironic distance, both the iconic imagery of the Russian revolutionary avant-garde and the stock imagery representing indigenous peoples as savages, because the film's aim is not to

37 Maksim Tuula, "Aleksei Fedorchenko: 'Eta istoriia o vtorzhenii liuboi tsivilizatsii v traditsionnoe obshchestvo," Biulleten' kinoprokatchika, June 8, 2015, accessed April 29, 2018, http://www.kinometro.ru/interview/show/name/Alexey_Fedorchenko_about Angels_of_Revolution_2346. On ethnographic cinema, see, for example, Karl G. Heider, Ethnographic Film (Austin, TX: University of Texas Press, 2006).

38 Oksana Sarkisova, Screening Soviet Nationalities: Kulturfilms from the Far North to Central Asia (London: I. B. Tauris, 2017), 64.

39 Corney, "Aleksei Fedorchenko."

40 Admittedly, Fesenko's (and his collaborators') script is dominated by an uneasy mutual attraction (absent from Aipin's book) between a priest's daughter and a revolutionary, at the expense of Khanty beliefs, legends and customs. Still, it may well be that even for the indigenous insiders-especially the authors educated in the Soviet system (such as Aipin) —it is not easy to express an unmediated point of view on their native history and culture, because most of their poetry and fiction "were written in Russian, and almost all were aimed at the Russian public. The activity of writing itself was nontraditional and had to rely on images, plots and tropes taken from Russian literature" (Slezkine, Arctic mirrors, 369). Fedorchenko shows the fruits of Soviet enlightenment in Angely's documentary epilogue, when Ekaterina Obatina, the first Khanty woman born at the Kazym kultbaza, who became a teacher of Russian and outlived the USSR by almost a quarter century, sings in front of the camera not a Khanty folk song, as is expected of her by the film crew, but the 1958 Soviet schlager "Pesnia o trevozhnoi molodosti" (A Song about a Turbulent Youth) by Lev Oshanin (lyrics) and Aleksandra Pakhmutova (music). 
demythologize the Russian Revolution in its relation to the indigenous cultures of the Soviet North but to remythologize it.

Insofar as filmmaking is about creating imaginary worlds that look convincingly real, it is, by its very nature, directly "related to mythmaking." Moreover, "in the contemporary age, one of the most powerful media that ... ensures the continuation of older myths, even as it alters them, is the medium of film." ${ }^{42}$ As Irving Singer explains,

by using the technical devices of panning, tracking, zooming, alternating shots that are close, medium, long, and all the rest of normal cinematography, as well as the systematic cutting that goes into the eventual editing, film instils in members of the audience a sense of distance from anything they might see outside the theater or within it before the lights are turned down. This distancing puts the spectators of the finished product into a receptive attitude toward narratives that are unlike life itself precisely because they are mythic or include mythic aspects... . Mythmaking depends upon our imaginative adherence to portrayals and events that we know to be unreal in any other context. At the same time, we are not just lured into but also engrossed by the quasi-realistic character of images that flit before our eyes in semblance of the world outside. The mythic experience combines both characteristics, the unreal as well as real. ${ }^{43}$

Retaining "the kind of one-to-one contact with a storyteller that some bard or shaman might effect in primitive societies," ${ }^{34}$ film can, and often does, serve as a bridge between the archaic and the advanced. In the words of Rachel O. Moore, "the camera is our one magical tool flush with animistic power to possess, enchant, travel through time and space, and bewitch.... Crafted as much by archaic beliefs and desires as by glass lenses, [it] joins the primitive to the modern." 45

41 S. Brent Plate, "Filmmaking, Mythmaking, Culture Making," in Representing Religion in World Cinema: Filmmaking, Mythmaking, Culture Making, ed. S. Brent Plate (New York and London: Palgrave Macmillan, 2003), 2.

42 Ibid., 6.

43 Irving Singer, Cinematic Mythmaking: Philosophy in Film (Cambridge, MA: The MIT Press, 2008), 9-10.

44 Ibid., 6.

45 Rachel O. Moore, Savage Theory: Cinema as Modern Magic (Durham and London: Duke University Press, 2000), 162-63. 
Fedorchenko has been making ample use of the cinematic opportunities for mythmaking and linking the archaic to the contemporary for quite some time now. His 2010 Ovsianki (a Russian word for buntings; this is another collaboration with Osokin, released in the West as Silent Souls) pretends to be a reconstruction of the rituals of the (non-existent) Finno-Ugric people of the Meria. ${ }^{46}$ Fedorchenko's 2012 Nebesnye zheny lugovykh mari (Celestial Wives of the Meadow Mari-yet another collaboration with Osokin) goes one step further and ascribes nonexistent beliefs and rituals to the very real, if not very numerous, Finno-Ugric Mari people. ${ }^{47}$ Unsurprisingly, Angely revoliutsii broadly follows the same path and has been defined by Fedorchenko himself as "historical facts and ancient myths, refracted through the lens of [the film crew's] imagination." 48

Why remythologize the indigenous resistance to the revolutionary changes, though, instead of telling the little-known yet deserving story of the Kazym rebellion as it was, documentary-style? Fedorchenko must have felt wary of documentary films as a genre. Their integrity has been compromised not only by Communist ideology (often too happy to subjugate facts to wishful thinking ${ }^{49}$ ), but also by the genre's early history. The word "documentary"

suggests observational neutrality, ... an unretouched record of what's real; and if that was the promise it was betrayed almost from the start... The British producer James Williamson filmed the Boer War on a golf course. Thomas Edison made a documentary of the RussoJapanese War on Long Island... . The Danish mogul Ole Olsen produced a safari documentary by buying a couple of aging lions from the Copenhagen zoo, moving them to an island, and, inter-cutting stock jungle footage, filming them being killed by hired "hunters." Audiences didn't seem to mind. ${ }^{50}$

46 For a review, see, for example, Serguei Oushakine, "Aleksei Fedorchenko: Silent Souls (Ovsianki, 2010)," Kinokultura 31 (2011), accessed April 30, 2018, http://www.kinokultura. com/2011/31r-buntings.shtml

47 For a review, see, for example, Andrei Rogatchevski, "Aleksei Fedorchenko: Celestial Wives of the Meadow Mari (Nebesnye zheny lugovykh Mari, 2012)," Kinokultura 41 (2013), accessed April 30, 2018, http://www.kinokultura.com/2013/41r-nebesnye-zheny.shtml.

48 Valerii Kichin, "Letiat nad Rimom angely," Rossiiskaia gazeta, October 17, 2014, accessed April 30, 2018, https://rg.ru/2014/10/17/premia-site.html.

49 Thus, Soviet documentaries of the 1930s about conquering the Arctic were quite adept at "turning failure into triumph" (Sarkisova, Screening Soviet Nationalities, 79).

50 Louis Menand, "Nanook and Me: Fahrenheit 9/11 and the Documentary Tradition," The New Yorker, August 9, 2004, accessed April 30, 2018, https://www.newyorker.com/magazine/2004/08/09/nanook-and-me. 
In a similar vein, but a hundred years later or so, Fedorchenko, who started out as a straightforward documentary filmmaker, ${ }^{51}$ released a feature-length motion picture Pervye na Lune (First on the Moon, 2005), about a 1938 secret Soviet space flight. ${ }^{52}$ To lend a semblance of credibility to this entirely improbable story, the film was disguised as a documentary. After its screening to the inhabitants of Star City near Moscow (home to the spacecraft manufacturer Energia), a former operator of the lunar module came up to the film director to confirm that the story narrated in Pervye na lune had taken place almost exactly as it had been told. ${ }^{53}$

Since then, (re)mythologization seems to have been Fedorchenko's preferred operating mode. He may have found this mode particularly appropriate when dealing with the subject of the Russian Revolution. After all, countering Bolshevik revolutionary myths with hard facts is nothing new. ${ }^{54}$ Contesting these myths with more myths of a comparable nature (implying, however, a very different moral lesson) may well have seemed a more original and challenging, and therefore more attractive, option.

In essence, the standard Bolshevik myth about revolutionaries sacrificing their own lives in adverse circumstances to make the world a better place is a variation on the monomyth — the hero's journey, which is subdivided into three principal stages (separation, initiation and return) and symbolizes the rites of passage. Joseph Campbell summarizes the monomyth thus: "A hero ventures forth from the world of common day into a region of supernatural wonder: fabulous forces are there encountered and a decisive victory is won: the hero comes back from his mysterious adventure with the power to bestow boons

51 See, for example, his shorts David (2002) and Deti beloi mogily (Children of the White Grave, 2003).

52 For a review, see, for example, Alexander Prokhorov, "The Redemption of Lunar Reality: Aleksei Fedorchenko's First on the Moon (Pervye na lune), 2005,” Kinokultura 11 (2006), accessed April 30, 2018, http://www.kinokultura.com/2006/11r-firstmoon2.shtml.

53 See Viktor Matizen, "Aleksei Fedorchenko: 'My ne poliruem vremia," Novye izvestiia, June 6, 2005, accessed April 30, 2018, https://newizv.ru/news/culture/06-06-2005/25646aleksej-fedorchenko.

54 Cf.: "From the first days in power the Bolsheviks tried to control the revolutionary narrative, creating a canonical view of selected events and their analysis, propagating it and eliminating the chances of breaking or even adjusting the canon. Locking away and destroying primary sources, documents and archives was part of this endeavor. It is not surprising that most of the counter-arguments and views outside the Bolsheviks' control were also formed within the framework set up by the Bolsheviks." Ekaterina Rogatchevskaia, "Introduction," in Russian Revolution: Hope, Tragedy, Myths, ed. Ekaterina Rogatchevskaia (London: The British Library, 2017), 22. 
on his fellow man." 55 The hero is often reluctant to embark on the journey, is persuaded to start regardless, by an older and wiser mentor, and is helped on the way by a company of magic assistants.

Campbell's follower David Adams Leeming describes the hero(ine)'s voyage in more detail, including, at the stages of initiation and return, his/ her possible death, visit to the realm of the dead, and subsequent resurrection: "The hero must confront physical death... . He descends to the underworld to confront the forces of death ... [and then] acts out humankind's most elementary desire- he overcomes death physically and is united with the natural cycle of birth, death and rebirth." 56

Angely's plot is not unlike a version of the monomyth, at least up to a point. Shneider does not want to travel to Kazym but is convinced to do so by the unnamed People's Commissar for Nationalities (played by Viktor Terelia), who knew her father and acts as her mentor. ${ }^{57}$ Her team of avant-gardists is of course little else but the hero(ine)'s helpers, while Kazym is the region of supernatural wonder (or the underworld), and the indigenous peoples stand for fabulous forces. This is where the parallels with the monomyth end, however, as Shneider and her helpers fail in their mission to overcome the natives. There is plenty of death in Angely, but no resurrection, and Shneider and her party will never return to their point of departure alive and victorious.

As for the Bolshevik hero(ine) in general, s/he may also perish, and does so more often than not-but never in vain. His/her deeds live on, s/he becomes a role model for others and is soon replaced by many more of those like him/her, just as heroic and self-sacrificial. This Bolshevik trope can be called "optimistic tragedy," after the title of the 1932 play by the Soviet dramatist Vsevolod Vishnevskii (1900-1951). In Angely revoliutsii, the tragedy is not counterbalanced by, or overloaded with, optimism. On the contrary, Shneider's mission feels like a complete and needless waste. With regard to the indigenous peoples, Fedorchenko's message could perhaps be expressed by Yuri Slezkine's phrase "The best colonial government [is] the least intrusive colonial government." 58

55 Joseph Campbell, The Hero with a Thousand Faces (New York: The World Publishing Company, 1968), 30.

56 David Adams Leeming, Mythology: The Voyage of the Hero (Oxford: Oxford University Press, 1998), 8.

57 For most of the Commissariate's existence it was run by Stalin.

58 Slezkine, Arctic Mirrors, 391. 
In the opinion of S. Brent Plate, "myths never end, they are merely retold in new forms." 59 In some people's minds, even today, myths may still play a more important role than historical facts. This is not necessarily a bad thing, provided that such myths teach us "what it is to be civilized humans." 60 When Fedorchenko claims that "little-known [historical] facts will be judged in accordance with [how they are represented in] Angely revoliutsii," ${ }^{61}$ he may be right and doing future generations a favor, quite irrespective of his deliberate factual inaccuracy.

\section{Bibliography and Filmography}

Adams Leeming, David. Mythology: The Voyage of the Hero. Oxford: Oxford University Press, 1998.

Aipin, Eremei. Bozh'ia Mater'v krovavykh snegakh. St. Petersburg: Amfora, 2010.

Balabanov, Aleksei. Kochegar (Russia, 2010, color, $87 \mathrm{~min}$ ), accessed May 14, 2018. https:// www.youtube.com/watch?v=RjJuTupeYcs.

Brent Plate, S. "Filmmaking, Mythmaking, Culture Making," in Representing Religion in World Cinema: Filmmaking, Mythmaking, Culture Making, edited by S. Brent Plate, 1-15. London: Palgrave Macmillan, 2003.

Campbell, Joseph. The Hero with a Thousand Faces. New York: The World Publishing Company, 1968.

Child, Lydia Maria. Brief History of the Condition of Women in Various Ages and Nations, vol. 1. New York: C. S. Francis, 1849.

Cohen, Leonard. Beautiful Losers. Toronto: McClelland and Stewart, 1966.

Corney, Frederick C. "Aleksei Fedorchenko: Angels of the Revolution (Angely revoliutsii, 2014)." Kinokultura 48 (2015). Accessed April 28, 2018. http://www.kinokultura.com/2015/48rangely-revoliutsii.shtml.

Ernykhova, Olga. Kazymskii miatezh: Ob istorii Kazymskogo vosstaniia 1933-34 gg. Novosibirsk: Sibirskii khronograf, 2003.

Fedorchenko, Aleksei. Angely revoliutsii (Russia, 2015, color, $105 \mathrm{~min}$ ). Accessed April 30, 2018. https://www.youtube.com/watch?v=LokBHuI8tTA.

Fesenko, Oleg. Krasnyi led: Saga o khantakh Iugry (Russia, 2009, color, 100 min). Accessed April 30, 2018. https://www.youtube.com/watch?v=Azkul9qgWdc.

59 S. Brent Plate, "Filmmaking, Mythmaking, Culture Making," 11.

60 Hannah Furness, "Children Should Be Taught Myths and Legends as 'Models for a Way of Life', Author Says," The Telegraph, October 31, 2013, accessed April 30, 2018, https://www. telegraph.co.uk/culture/books/booknews/10410270/Children-should-be-taught-mythsand-legends-as-models-for-a-way-of-life-author-says.html.

61 Vizgalova, "Aleksei Fedorchenko." 
Filippov, Aleksei. “Angely revoliutsii: Rossiia, kotoruiu my ne nashli.” Kino-teatr.ru, November 1, 2015. Accessed April 28, 2018. http://www.kinoteatr.ru/kino/art/pr/4181/.

Flaherty, Robert J. Nanook of the North (USA, black \& white, 1922, 79 min). Accessed May 15, 2018. https://www.youtube.com/watch?v=m4kOIzMqso0.

Furness, Hannah. "Children Should Be Taught Myths and Legends as 'Models for a Way of Life', Author Says." The Telegraph, October 31, 2013. Accessed April 30, 2018. https://www. telegraph.co.uk/culture/books/booknews/10410270/Children-should-be-taught-mythsand-legends-as-models-for-a-way-of-life-author-says.html.

Harris, Brent. "Photography in Colonial Discourse: The Making of the 'Other' in Southern Africa, c. 1850-1950." In The Colonising Camera: Photographs in the Making of Namibian History, edited by Wolfram Hartmann, Jeremy Silvester and Patricia Hayes, 20-24. Cape Town: University of Cape Town Press, 1998.

Heider, Karl G. Ethnographic Film. Austin: University of Texas Press, 2006.

Kichin, Valerii. "Letiat nad Rimom angely." Rossiiskaia gazeta, October 17, 2014. Accessed April 30, 2018. https://rg.ru/2014/10/17/premia-site.html.

. "Shamany protiv revoliutsii: Aleksei Fedorchenko rasskazal v Rime o stolknovenii tsivilizatsii.” Rossiiskaia gazeta, October 22, 2014. Accessed April 28, 2018. https:// rg.ru/2014/10/22/film-site.html.

Lungin, Pavel. Luna Park (Russia/France, 1992, color, 111 min). Accessed May 14, 2018. https://www.youtube.com/watch?v=JEHMnkoyO-0.

Lunkova, Olga. "Shamany protiv Sovetskoi vlasti: V prokat vyshel film Alekseia Fedorchenko Angely revoliutsii." Teatral-online.ru, November 12, 2015. Accessed April 28, 2018. http://www.teatral-online.ru/news/14674.

Mamadnazarbekova, Kamila. "Aleksei Fedorchenko: 'Istoriia nas dognala.” Vedomosti, June 23, 2015. Accessed 30 April, 2018. https://www.vedomosti.ru/lifestyle/characters/ 2015/06/24/597689-aleksei-fedorchenko-istoriya-nas-dognala.

Matizen, Viktor. "Aleksei Fedorchenko: 'My ne poliruem vremia.” Novye izvestiia, June 6, 2005. Accessed April 30, 2018. https://newizv.ru/news/culture/06-062005/25646-aleksejfedorchenko.

Mauss, Marcel. The Gift: Forms and Functions of Exchange in Archaic Societies, translated by Ian Cunnison. London: Cohen and West, 1966.

Maxwell, Anne. Colonial Photography and Exhibitions: Representations of the "Native" People and the Making of European Identities. London: Leicester University Press, 1999.

Menand, Louis. "Nanook and Me: Fahrenheit 9/11 and the Documentary Tradition." The New Yorker, August 9, 2004. Accessed April 30, 2018. https://www.newyorker.com/ magazine/2004/08/09/nanook-and-me.

Moore, Rachel O. Savage Theory: Cinema as Modern Magic. Durham: Duke University Press, 2000.

Oushakine, Serguei. "Aleksei Fedorchenko: Silent Souls (Ovsianki, 2010)." Kinokultura 31 (2011). Accessed April 30, 2018. http://www.kinokultura.com/2011/31r-buntings.shtml. 
Prokhorov, Alexander. "The Redemption of Lunar Reality: Aleksei Fedorchenko's First on the Moon (Pervye na lune), 2005." Kinokultura 11 (2006). Accessed April 30, 2018. http://www. kinokultura.com/2006/11r-firstmoon2.shtml.

Pyrev, Ivan. Svinarka i pastukh (USSR, 1941, black \& white, 88 mins). Accessed May 14, 2018. https://www.youtube.com/watch?v=f-Vdt6CrHBQ.

Rogatchevskaia, Ekaterina. "Introduction." In Russian Revolution: Hope, Tragedy, Myths, edited by Ekaterina Rogatchevskaia, 21-25. London: The British Library, 2017.

Rogatchevski, Andrei. "Aleksei Fedorchenko: Celestial Wives of the Meadow Mari (Nebesnye zheny lugovykh mari, 2012)." Kinokultura 41 (2013), accessed April 30, 2018. http://www. kinokultura.com/2013/41r-nebesnye-zheny.shtml.

Rogozhkin, Aleksandr. Kukushka (Russia, 2002, color, $100 \mathrm{~min}$ ), accessed May 14, 2018. https://www.youtube.com/watch?v=34qTK6KJZqg.

Sarkisova, Oksana. Screening Soviet Nationalities: Kulturfilms from the Far North to Central Asia. London: I. B. Tauris, 2017.

Schuchov, I. N. Der Fluss Kazym und seine Anwohner: Ergebnisse einer 1914 unternommenen Exkursion, trans. Katharina Oestreich-Geib. München: Veröffentlichungen des FinnischUgrischen Seminars an der Universität München, 1980.

Silvester, Jeremy, Patricia Hayes and Wolfram Hartmann, “'This Ideal Conquest': Photography and Colonialism in Namibian History." In The Colonising Camera: Photographs in the Making of Namibian History, edited by Wolfram Hartmann, Jeremy Silvester and Patricia Hayes, 10-19. Cape Town: University of Cape Town Press, 1998.

Singer, Irving. Cinematic Mythmaking: Philosophy in Film. Cambridge, MA: The MIT Press, 2008.

Slezkine, Yuri. Arctic Mirrors: Russia and the Small Peoples of the North. Ithaca: Cornell University Press, 1994.

Solntseva, Alena. "Aleksei Fedorchenko: 'Bogi skazali, chto nado prinesti chuzhikh v zhertvu." The New Times, June 9, 2015. Accessed April 29, 2018. https://newtimes.ru/articles/ detail/98929/.

Tuula, Maksim. "Aleksei Fedorchenko: 'Eta istoriia o vtorzhenii liuboi tsivilizatsii v traditsionnoe obshchestvo.” Biulleten' kinoprokatchika, June 8, 2015. Accessed April 29, 2018. http://www.kinometro.ru/interview/show/name/Alexey_Fedorchenko_about_Angels_ of_Revolution_2346.

Vertov, Dziga. Shestaia chast' mira (USSR, black \& white, 1926, 75 min). Accessed May 15, 2018. https://www.youtube.com/watch?v=NAwZM177zRg.

Vizgalova, Ekaterina. "Aleksei Fedorchenko: 'Narod, kotoryi dolzhen byt' zainteresovan v svoei istorii, nichego ne znaet.” Kino-teatr.ru, November 7, 2015. Accessed April 28, 2018. https:// www.kino-teatr.ru/teatr/person/483/. 